\title{
ANALISIS SILDENAFIL SITRAT DALAM JAMU KUAT DI KECAMATAN BOGOR BARAT DAN TANAH SAREAL DENGAN MENGGUNAKAN KROMATOGRAFI CAIR SPEKTROMETRI MASSA
}

\author{
Triyani Sumiati1*1, Bina Lohita².,Nurtiyah ${ }^{3}$ \\ 1Program Studi Farmasi Sekolah Tinggi Teknologi Industri dan Farmasi Bogor \\ 2Program Studi FarmasiUniversitas Pakuan Bogor \\ 3Program Studi S1 Farmasi Sekolah Tinggi Teknologi Industri dan Farmasi Bogor \\ Korespondensi: triyanisumiati@gmail.com
}

\begin{abstract}
ABSTRAK
Jamu merupakan pengobatan pilihan masyarakat karena berkhasiat menjaga kesehatan tubuh manusia. Salah satu jenis jamu adalah jamu kuat yang dapat berkhasiat sebagai penambah stamina dan vitalitas lelaki, namun dalam perkembangannya kemurnian jamu kuat banyak ditambahkan sildenafil sitrat oleh pihak yang tidak bertanggung jawab. Penelitian ini merupakan penelitian eksperimental dengan rancangan analisis deskriptif. Analisis senyawa sildenafil sitrat dengan menggunakan Kromatografi Lapis Tipis (KLT) dan Kromatografi Cair Spektrometri Massa (KC-SM) yang disampling pada 2 kecamatan yaitu kecamatan Bogor Barat dan Tanah Sareal sehingga diperoleh 32 sampel, dimana 18 sampel dari Bogor Barat diberi kode A dan 14 sampel dari Tanah Sareal diberi kode B. Hasil KLT yang dielusi pada Silica gel $60 \mathrm{~F}_{254}$ dengan eluen metanol:kloroform (4:1), terdapat 5 sampel menunjukkan nilai Rf yang mendekati standar sildenafil sitrat yaitu 0.83 , pada kode sampel A4 nilai Rf 0,84, A13 nilai Rf 0,84, A17 nilai Rf 0,83, B11 nilai Rf 0,83, dan B14 nilai Rf 0,84. Hasil KCSM dengan menggunakan kolom Phenomenex Synergi Fusion RP-100A, sistem pompa gradien dengan fase gerak 0,2 $\mathrm{M}$ amonium asetat $\mathrm{pH} 7$ dalam air dan 0,2 $\mathrm{M}$ amonium asetat $\mathrm{pH} 7$ dalam asetonitril, diperoleh kadar sampel untuk kode A4, A13, A17, B11, B14 sebesar 198,01; 1119.19; 226,00; 156,77; $443,87 \mu \mathrm{g} / \mathrm{kg}$.
\end{abstract}

\section{Kata kunci $\quad$ : jamu, KC-SM, KLT, sildenafil sitrat}

\begin{abstract}
Herbal medicineisthe treatment of choicebecause ofmerit in maintainingthe health ofthe peopleof the human body. Strongherbal medicineisherbal medicinethat isefficacious asstaminaandvitality ofman, but in its developmentpuritypowerfulherbsare addedsildenafilcitratebyparties who are notresponsible. This study was adescriptiveanalysis ofexperimentaldesign. Analysis of sildenafilcitrate compounds using Thin Layer Chromatography (TLC) and Liquid Chromatography Mass Spectrometry (LC-MS) were sampled in two districts, namely sub-district, Bogor Barat and Tanah Sareal thus obtained 32 samples, of which 18 samples of Bogor Barat coded A and 14 samples from Tanah Sareal coded B. TLC results were eluted at Silica gel 60 F254 with eluent methanol:chloroform (4:1), there were 5 samples showed close $\mathrm{Rf}$ value standard sildenafil citrate is 0.83 , the sample code A4 value of Rf 0.84 , A13 Rf value of 0.84 , A17 Rf value of 0.83 , B11 Rf value of 0.83 , and B14 Rf value of 0.84 . Results LC-MS where separation using column Phenomenex Synergi Fusion RP-100A, the pumping system with a mobile phase gradient of $0.2 \mathrm{M}$ ammonium acetate $\mathrm{pH} 7$ in water and $0.2 \mathrm{M}$ ammonium acetate pH 7 in acetonitrile, was obtained the samples for A4, A13, A17, B11 dan B14 amounted to 198.01; $1734.14 ; 226.00 ; 156.77 ; 443.87 \mu \mathrm{g} / \mathrm{kg}$
\end{abstract}

Keywords : jamu, LC-MS, sildenafil citrate, TLC 


\section{PENDAHULUAN}

Jamu adalah obat tradisional berbahan alami warisan budaya yang telah diwariskan secara turun-temurun dari generasi ke generasi untuk kesehatan. Pengertian jamu dalam Peraturan menteri kesehatan No.003/Menkes/Per/I/2010 adalah bahan atau ramuan bahan yang berupa tumbuhan, bahan hewan, bahan mineral, sediaan sarian (galenik), atau campuran dari bahan tersebut yang secara turun temurun telah digunakan untuk pengobatan, dan dapat diterapkan sesuai dengan norma yang berlaku di masyarakat.

Sebagian besar masyarakat mengkonsumsi jamu karena dipercaya memberikan andil yang cukup besar terhadap kesehatan baik untuk pencegahan dan pengobatan terhadap suatu penyakit maupun dalam hal menjaga kebugaran, kecantikan dan meningkatkan stamina tubuh. Menurut WHO, sekitar $80 \%$ dari penduduk dibeberapa negara Asia dan Afrika menggunakan obat tradisional untuk mengatasi masalah kesehatannya.Sekitar 70-80\% masyarakat di negara maju telah menggunakan beberapa bentuk pengobatan komplementer atau alternatif serta obat herbal.

Sebanyak 51 produk obat tradisional ditarik dari peredaran oleh Badan Pengawasan Obat dan Makanan (BPOM). Produk-produk tersebut mengandung bahan kimia obat, yang bisa memicu efek samping berbahaya jika dikonsumsi sembarangan. Sebagian besar didominasi jamu penghilang rasa sakit, jamu kuat dan jamu pembangkit gairah seks pria dewasa.[1]

Menurut peraturan Menteri Kesehatan Republik Indonesia nomor 246 pasal 39 yang menyatakan bahwa "Industri obat tradisional atau industri kecil obat tradisional dilarang memproduksi segala jenis obat tradisional yang mengandung bahan kimia hasil isolasi atau sintetik yang berkhasiat obat" dan kesehatan serta keselamatan masyarakat dapat terlindungi, maka perlu dilakukan pengawasan terhadap produk jamu yang beredar dipasaran.

Jamu penambah stamina pria atau yang lebih dikenal dimasyarakat sebagai jamu kuat pria ini telah banyak beredar dipasaran baik yang telah mendapatkan label BPOM maupun yang tidak berlabel BPOM.

Produk jamu obat kuat merupakan bahan alam berkhasiat yang telah diformulasikan oleh produsen tidak boleh mengandung zat kimia seperti sildenafil sitrat yang ditambahkan dalam jamu, maka perlu diujikan kembali kandungan zat-zat yang terdapat dalam jamu.

Sildenafil sitrat merupakan salah satu jenis obat baru yang masih dipasarkan sebagai produk patennya, yaitu Viagra ${ }^{\circledR}$ dan Revatio ${ }^{\circledR}$. Sildenafil merupakan salah satu senyawa yang digunakan dalam terapi disfungsi ereksi atau lebih dikenal dengan istilah anti impotensi golongan inhibitor fosfodiesterase. Selain digunakan dalam terapi disfungsi ereksi, sildenafil juga digunakan dalam pulmonary arterial hypertension (PAH). [2]

Mekanisme kerja obat ini adalah melalui penghambatan konversi trifosfat guanilat menjadi monophosphate guanosin cyclic (cGMP). cGMP merupakan neurotransmiter vasodilator pada jaringan. Katabolisme cGMP dimediasi oleh enzim fosfodiesterase. Tiga isoenzim fosfodiesterase tipe 5 dengan selektivitas yang tinggi ditemukan pada jaringan genital, yang menurunkan katabolisme cGMP. Penghambatan fosfodiesterase pada jaringan nongenital menghasilkan efek yang merugikan. [3]

Senyawa penghambat fosfodiesterase yang beredar dimasyarakat yaitu sildenafil sitrat ini memiliki profil farmakokinetik, interaksi obat-makanan, dan efek samping seperti sakit kepala, muka merah, pusing, mual, nyeri perut, gangguan penglihatan, nyeri dada, jantung berdetak kencang. Peringatan dan perhatian khusus harus diberikan pada pasien dengan penyakit kardiovaskuler yang juga menerima sildenafil atau penghambat fosfodiesterase lainnya.

Penelitian kandungan sildenafil sitrat yang dilakukan dengan pelarut asetonitril:dapar fosfat $0,05 \mathrm{M} \mathrm{pH}$ 4,5 dengan perbandingan (60:40) yang dianalisis dengan metode Kromatografi Cair Kinerja Tinggi (KCKT) sebelumnya dapat mendeteksi adanya kandungan sildenafil sitrat dalam jamu kuat lelaki sebesar $0,313 \mathrm{mg} / \mathrm{g}$. [4] Namun masih perlu dilakukan metode pengukuran dengan menggunakan metode lain yang lebih selektif dalam mengukur kandungan senyawa kimia sildenafil sitrat dalam jamu kuat lelaki.

Berdasarkan pada uraian di atas maka perlu dilakukan penelitian analisis sampel jamu kuat yang ada di pasaran untuk 
penentuan kandungan zat aktif yang berkhasiat sebagai penambah stamina pria yaitu sildenafil sitrat dengan menguji secara kualitatif dan kuantitatif dengan metode yang selektif untuk kadar dengan konsentrasi rendah menggunakan alat Kromatografi Cair Spektrometri Massa (KC-SM).SPEKTOMS) Penelitian ini dapat dijadikan suatu referensi analisis Bahan Kimia Obat (BKO) dalam jamu dan mengembangkan pengetahuan terhadap pengawasan industri jamu.

\section{METODE PENELITIAN}

Bahan: Bahan yang digunakan dalam penelitian ini adalah sampel jamu kuat yang diperoleh dari hasil sampling pada pasar yang telah ditentukan, aquabidest, asam asetat glasial grade Merck, asetonitril LC grade Merck, metanol LC grade Merck, hablur amonium format Fluka grade Merck, etil asetat grade Merck, amonium hidroksida grade Merck, kloroform grade Merck, standar sildenafil sitrat (Sigma Aldrich).

Alat: Alat yang digunakan dalam penelitian ini adalah neraca analitik Sartorius CPA 225D, peralatan gelas, silika gel $\mathrm{GF}_{254}$, camag linomat $v$, reprostar, penyangga kertas, benang wol, pensil dan penggaris, pompa vakum Milipore Waters, tabung sentrifugasi $50 \mathrm{~mL}$, alat sentrifugasi, mikropipet Eppendorf 10-100 $\mu \mathrm{L}$ dan $100-1000 \mu \mathrm{L}$, membran filter GHP PALLф $0,22 \mu \mathrm{m}$, syringe filter GHP PALLф $0,22 \mu \mathrm{m}$, syringe $10 \mathrm{~mL}$, vial $2 \mathrm{~mL}, U P L C$ $M S / M S \quad$ Waters-ABSCIEx 4500 QTrap SelexION ${ }^{\mathrm{TM}}$, guard kolom (Phenomenex Synergy Guard), kolom Phenomenex Synergy Fusion $C_{18}$ 100A dan kolom Aquity BEH $C_{18} 100 \mathrm{~mm}$.

\section{Metode}

\section{Lingkup Kerja}

Jenis penelitian ini adalah analisis deskriptif, yaitu menganalis kandungan zat aktif sildenafil sitrat dalam produk jamu yang dijual oleh pedagang jamu di Kota Bogor. Pemilihan pedagang jamu yang diambil sebagai sampel mempunyai kriteria sebagai berikut:

1. Lokasi yang strategis dan mudah dijangkau oleh konsumen.

2. Tempat penjualan menetap tidak berpindahpindah.
3. Pedagang yang sudah terkenal di kalangan masyarakat di kecamatan Bogor Barat dan kecamatan Tanah Sareal.

Pengambilan sampel menggunakan metode sampling purposive sampling. Tujuan dari metode sampling adalah untuk mengadakan estimasi dan mengkaji hipotesis tentang parameter populasi dengan menggunakan keterangan-keterangan yang diperoleh dari sampel jamu.

\section{Survei dan pengambilan sampel}

Daerah atau area sampling terdiri dari 16 kelurahan yang ada di Kecamatan Bogor Barat, yaitu
1. Semplak
9. Pasir Kuda
2. Curug Mekar
10. Pasir Mulya
3. Cilendek Barat
11. Pasir Jaya
4. Cilendek Timur
12. Marga Jaya
5. Menteng
13. Situ Gede
6. Sindang Barang
14. Bubulak
7. Loji
8. Gunung Batu
15. Balumbang Jaya
16. Curug

Sebanyak 16 kelurahan di Bogor Barat yang disampling terdapat 17 toko jamu dengan 18 sampel jamu kuat yang memenuhi kriteria untuk diuji yaitu dengan mengambil sampel yang tertera pada label kemasan dengan indikasi untuk menambah stamina dan vitalitas pria.

Daerah atau area sampling terdiri dari 11 kelurahan yang ada di Kecamatan Tanah Sareal, yaitu:
1. Tanah Sareal
7. Sukaresmi
2. Kebon Pedes
8. Cibadak
3. Kedung Badak
9. Kencana
4. Kedung Jaya
10. Mekarwangi
Kedung
5. Waringin
11. Kayumanis
6. Sukadamai

Pada 11 kelurahan di Tanah Sareal terdapat 13 toko jamu dengan 14 sampel jamu kuat yang di sampling memenuhi kriteria untuk di uji. Pedagang jamu diambil secara acak dari tiap kelurahan yang telah ditentukan, kemudian dihitung banyaknya pedagang jamu yang 
menetap kemudian diambil 2 pedagang jamu secara acak. Teknik ini bertujuan menghindari kemungkinkan adanya keragaman, baik keragaman dalam kelompok maupun ulangan.

Sampel jamu diambil kemudian diuji kandungan zat aktif sildenafil sitrat secara kualitatif menggunakan KLT. Apabila hasil positif maka dilanjutkan dengan cara kuantitatif menggunakan KCSM.

\section{Analisis Kualitatif (Kromatografi Lapis Tipis)}

a. Persiapan Sampel

Penimbangan sampel dilarutkan 1 gram sampel dengan metanol, larutan di ultrasonik 30-60 menit, disentrifugasi selama 5 menit dengan kecepatan 14000 $\mathrm{rpm}$. Lalu disaring larutan dengan filter PTFE/GHP diameter pori $0,2 \mu \mathrm{m}$, kemudian larutan ekstrak siap di spot pada media KLT.

b. Teknik Elusi KLT

Fase gerak untuk mengelusi dibuat dengan cara mencampurkan $80 \mathrm{ml}$ metanol dan 20 $\mathrm{ml}$ kloroform dengan perbandingan 4:1, kemudian dimasukkan ke dalam chamber dan dijenuhkan eluen metanol : kloroform (4: 1) sebanyak $100 \mathrm{ml}$. Larutan untuk spoting dibuat dengan cara ditimbang 1 gram ke labu $10 \mathrm{ml}$. Dilarutkan dengan metanol, lalu didiamkan dalam ultrasonik selama 30-60 menit. Larutan dihimpitkan hingga tanda tera dengan metanol. Larutan dipusingkan dengan alat sentrifugasi. Bagian yang jernih disaring dengan saringan milipore PTFE/GHP 0,2 $\mu \mathrm{m}$. Larutan ditampung di bagian bawah dalam botol vial dan ditotolkan pada lempeng kemudian dielusi. Titik spot yang terbentuk di catat dan dihitung nilai Rf. [5]

\section{Analisis Kuantitatif (Kromatografi Cair Spektrometri Masa)}

a. Pembuatan larutan Standar

Larutan standar 1000 ppm sildenafil sitrat dibuat dengan menimbang standar sebanyak $5 \mathrm{mg}$ ke dalam vial $5 \mathrm{~mL}$. Kemudian, dilarutkan dengan metanol, diultrasonik selama 15 menit, lalu ditambahkan hingga tanda tera dengan pelarut metanol LC grade. Selanjutnya, dibuat standar induk kedua, yaitu $1000 \mathrm{ppb}$ atau $1 \mathrm{ppm}$ dengan membuat standar induk antara $10 \mathrm{ppm}$.
Larutan standar dibuat antara $100 \mathrm{ppb}$ dan $50 \mathrm{ppb}$. Deret standar dibuat dengan lima jenis konsentrasi yang disesuaikan, yaitu 5; 7,5; 10; 25 dan $50 \mathrm{ppb}$ pada labu $10 \mathrm{~mL}$. Deret standar yang telah dibuat disaring dengan saringan milipore PTFE/GHP 0,2 $\mu \mathrm{m}$, kemudian dimasukkan kedalam vial 2 $\mathrm{mL}$.

b. Pembuatan fase Gerak dalam Sistem Kromatografi

Fase gerak yang digunakan adalah 0,2 $\mathrm{M}$ amonium asetat $\mathrm{pH} 7$ dalam aquabides (pompa A) dan 0,2 $\mathrm{M}$ amonium asetat dalam asetonitril (pompa B). Digunakan dua buah labu ukur $250 \mathrm{~mL}$ untuk pembuatan fase gerak. Amonium asetat ditimbang 3,85 g ke dalam masing-masing labu ukur $250 \mathrm{~mL}$, kemudian dilarutkan dengan $25 \mathrm{~mL}$ air untuk fase gerak $\mathrm{A}$ dan $250 \mathrm{~mL}$ asetonitril untuk fase gerak B. Fase gerak $\mathrm{A}$ diatur $\mathrm{pH}$ hingga $\mathrm{pH} 7$ dengan asam asetat atau amonium format, lalu ditambahkan air hingga tanda tera

\section{Kondisi Instrumentasi $[6,7]$}

a. Uji Pendahuluan Sistem Spektroskopi masa Uji pendahuluan dilakukan untuk menentukan massa/muatan $(\mathrm{m} / \mathrm{z})$ sildenafil sitrat.Standar dibuat dengan konsentrasi 50 ppb. Jenis ionisasi yang digunakan adalah ESI (Electrospray Ionization) berpolaritas (+) dengan suhu ion source $400^{\circ} \mathrm{C}$, curtain gas 30 Psi, CAD (collisiongas) medium, ionspray voltage 1500 volt, dan $\mathrm{GS}_{1}$ serta $\mathrm{GS}_{2}$ sebesar 50 Psi dan 60 Psi. Sedangkan, scan mode yang digunakan adalah MRM (Multiple Reaction Monitoring) sesuai dengan hasil uji pendahuluan (optimasi) masing-masing analit dalam sampel.

b. Sistem Kromatografi cair Kinerja UltraKondisi UPLC (Ultra Performance Liquid Chromatography) meliputi kecepatan alir $0,4 \mathrm{~mL} / \mathrm{min}$. Sistem pompa yang digunakan adalah metode gradien dengan komposisi sebagai berikut.

Tabel 1. Komposisi Fase Gerak

\begin{tabular}{cccc}
\hline $\begin{array}{c}\text { Waktu } \\
\text { (menit) }\end{array}$ & $\begin{array}{c}\text { LajuAlir } \\
(\mathbf{m L} / \text { menit })\end{array}$ & $\begin{array}{c}\text { A } \\
(\boldsymbol{\%})\end{array}$ & $\begin{array}{c}\text { B } \\
(\boldsymbol{\%})\end{array}$ \\
\hline 00:00:01 & 0,4 & 90 & 10 \\
00:03:00 & 0,4 & 10 & 90
\end{tabular}




\begin{tabular}{llll}
$00: 04: 48$ & 0,4 & 10 & 90 \\
00:05:03 & 0,4 & 90 & 10 \\
00:06:30 & 0,4 & 90 & 10 \\
\hline
\end{tabular}

Keterangan :

$\mathrm{A}=$ Fase gerak 0,2 $\mathrm{M}$ Amonium asetat dalam aquabides

$\mathrm{B}=$ Fase gerak 0,2 $\mathrm{M}$ Amonium asetat dalam asetonitril

Kolom yang digunakan adalah Phenomenex Synergy Fusion RP-100A yang dilengkapi dengan guard column Security Guard Phenomenex Column. Suhu kolom diatur pada $35^{\circ} \mathrm{C}$. Volume injeksi adalah $5 \mu \mathrm{L}$. [8]

\section{Perhitungan kadar}

Dengan menggunakan kurva kalibrasi deret standar $\mathrm{y}=\mathrm{ax}+\mathrm{b}$, konsentrasi analit yang diinginkan dapat diketahui.

\section{Metode analisis sampel}

Metode analisis yang digunakan merupakan metode analisis uji sildenafil sitrat secara simultan. Metode ini disadur dari metode App. NoteCliquid Method ABSCIEX (Experimental Conditions to Analyze Drugs using the MRM Catalogue) tentang analisis bahan kimia obat. Sampel yang telah dihomogenkan (diblender) ditimbang sebanyak 1 gram, dilarutkan dengan $10 \mathrm{ml}$ larutan metanol, lalu dikocok selama 1 menit. Sentrifugasi dilakukan dengan kecepatan 14000 rpm selama 5 menit untuk memisahkan padatan dengan cairan jernih. Fase bagian atas (fase metanol) yaitu filtrat disaring dengan GHP Membrane filter berukuran 0,20 $\mu \mathrm{m}$, larutan siap diinjeksikan ke dalam sistem KCSM.

\section{HASIL DAN PEMBAHASAN \\ Hasil Survei dan pengambilan sampel}

Penelitian ini terlebih dahulu dilakukan survei jumlah pedagang jamu yang menetap wilayah Kecamatan Bogor Barat dan Tanah Sareal. Penelitian meggunakan metode purposive sampling dalam penelitian ini. Purposive sampling adalah metode pengambilan sampel yang dipilih dengan cermat sehingga relevan dengan struktur penelitian.Jumlah sampel yang diperoleh dari Kecamatan Bogor Barat yang terdiri dari 16 kelurahan diperoleh sampel jamu kuat sebanyak 18 sampel dan Kecamatan Tanah Sareal yang terdiri dari 11 kelurahan sebanyak 14 sampel jamu kuat. Pemberian label pada sampel yang diteliti dibedakan menjadi dua kelompok, dimana Kecamatan Bogor Barat peneliti berikan kode A (A1 sampai A18) dan Kecamatan Tanah Sareal peneliti berikan kode B (B1 sampai B14)

\section{Hasil Uji Kromatografi Lapis Tipis}

Kromatografi lapis tipis dengan metode pemisahan partisi dapat digunakan untuk pemisahan senyawa polar. Nilai $\mathrm{Rf}$ didefinisikan sebagai perbandingan jarak yang ditempuh oleh senyawa pada permukaan fase diam dibagi dengan jarak yang ditempuh oleh pelarut sebagai fase gerak. Semakin besar nilai Rf dari sampel maka semakin besar pula jarak bergeraknya senyawa tersebut pada plat kromatografi lapis tipis. Senyawa yang memiliki Rf lebih besar berarti mempunyai kepolaran yang rendah, begitu juga sebaliknya. Hal tersebut dikarenakan fase diam bersifat polar. [9]

Berdasarkan pada hasil pengujian KLT dapat diketahui nilai $\mathrm{Rf}$ standar dan sampel yang positif mengandung sildenafil sitrat tercantum pada Tabel 4. 
Tabel 2. Nilai Rf dari sampel yang positif dan standar sildenafil sitrat

\begin{tabular}{|c|c|c|c|}
\hline $\begin{array}{l}\text { Kode sampel } \\
\text { dan standar }\end{array}$ & $\begin{array}{l}\text { Jarak tempuh eluen } \\
(\mathrm{cm})\end{array}$ & $\begin{array}{l}\text { Jarak tempuh komponen } \\
(\mathrm{cm})\end{array}$ & $\begin{array}{l}\text { Nilai } \\
\text { Rf }\end{array}$ \\
\hline $\mathrm{A} 4$ & \multirow{8}{*}{10} & 8,4 & 0,84 \\
\hline A13 & & 8,4 & 0,84 \\
\hline A17 & & 8,2 & 0,82 \\
\hline B11 & & 8,3 & 0,83 \\
\hline B14 & & 8,3 & 0,83 \\
\hline ST 1 (1000 ppm) & & 8,3 & 0,83 \\
\hline ST 2 (100 ppm) & & 8,3 & 0,83 \\
\hline ST 3 (10 ppm) & & 8,3 & 0,83 \\
\hline
\end{tabular}

Hasil KLT yang tercantum di Lampiran 8 merupakan hasil penyinaran sinar UV pada panjang gelombang $254 \mathrm{~nm}$ dideteksi terdapat 5 sampel jamu kuat yang memiliki nilai $\mathrm{Rf}$

yang sama dengan standar dan menghasilkan sinar berwarna biru berfluoresen yang sesuai dengan standar.

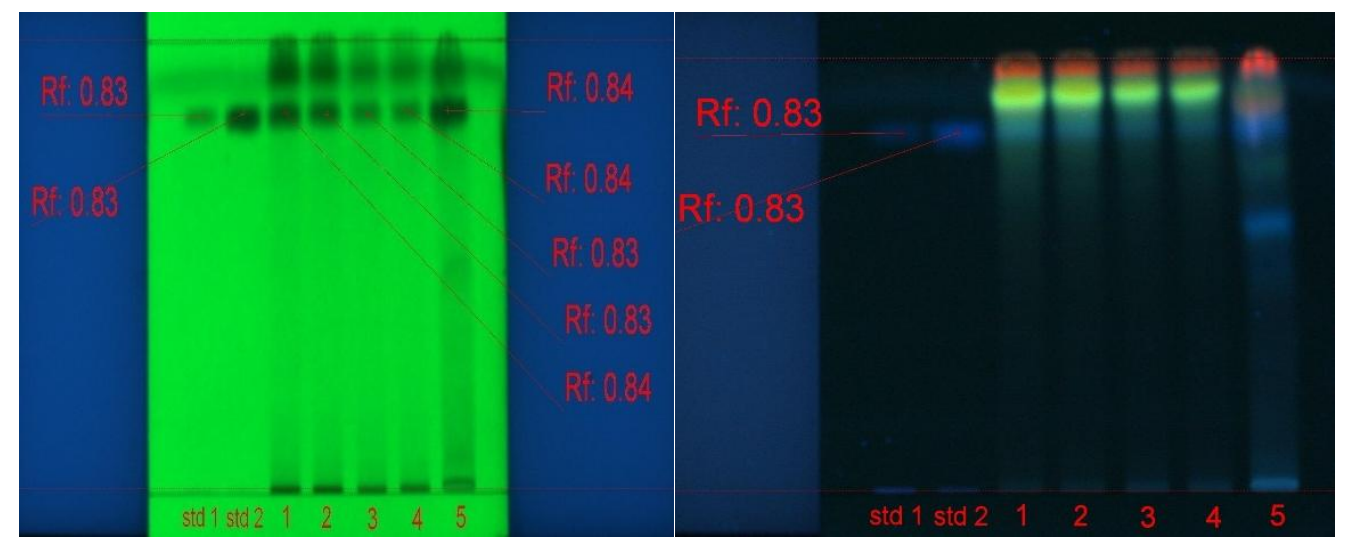

Gambar 1. Hasil KLT pada panjang gelombang 254 nm (a) dan 366 nm (b)

Keterangan :

Std $1=$ standar sildenafil 100 ppm nilai Rf 0,83

Std $2=$ standar sildenafil 1000 ppm nilai Rf 0,83

$1=$ kode sampel A4 nilai Rf 0,84

$2=$ kode sampel $\mathrm{A} 13$ nilai $\mathrm{Rf} 0,84$

$3=$ kode sampel $\mathrm{A} 17$ nilai $\mathrm{Rf} 0,83$

$4=$ kode sampel B11 nilai $\mathrm{Rf} 0,83$

$5=$ kode sampel B14 nilai $\mathrm{Rf} 0,84$

Pada Gambar 1, lempeng akan berflouresensi sedangkan sampel akan tampak berwarna gelap.Penampakan noda terlihat hijau pada sinar UV dengan panjang gelombang 254 $\mathrm{nm}$ adalah karena adanya daya interaksi antara sinar UV dengan indikator fluoresensi yang terdapat pada lempeng/plat jenis silica gel GF 254, jenis silika gel ini akan berfluoresensi kehijauan jika dilihat pada sinar UV dengan panjang gelombang pendek yakni $254 \mathrm{~nm}$.[10] Pada UV $366 \mathrm{~nm}$ noda akan berflouresensi dan lempeng akan berwarna gelap. Penampakan noda pada lampu UV $366 \mathrm{~nm}$ adalah karena adanya daya interaksi antara sinar UV dengan gugus kromofor yang terikat oleh auksokrom yang ada pada noda tersebut. Fluoresensi cahaya yang tampak merupakan emisi cahaya yang dipancarkan oleh komponen tersebut 
ketika elektron yang tereksitasi dari tingkat energi dasar ke tingkat energi yang lebih tinggi kemudian kembali ke keadaan semula sambil melepaskan energi. Sehingga noda yang tampak pada lampu UV $366 \mathrm{~nm}$ terlihat terang berwarna biru tua karena silika gel yang digunakan tidak berfluoresensi pada sinar UV $366 \mathrm{~nm}$.

\section{Hasil uji pada Kromatografi Cair Spektrometri Massa (KCSM)}

Kandungan sildenafil sitrat pada KCSM didasarkan pada pemisahan sampel hasil preparasi dilanjutkan ekstraksi fasa padat pada kolom berdasarkan pada perbedaan interaksi analit dengan fase diam (packing material column) dan fase gerak (mobile phase)yang berbeda komponen laininya di dalam sampel. Spektrometri massa menganalisa senyawa yang bekerja berdasarkan pengukuran bobot molekul per muatan $(\mathrm{m} / \mathrm{z})$. Oleh karena itu detektor spektrometri massa merupakan detektor yang universal dan selektif. Universal karena setiap senyawa yang pasti memiliki bobot molekul, selektif karena setiap senyawa umumnya memiliki bobot molekul yang berbeda-beda.

+MRM (20 pairs) 1.958 min from Sildenafil

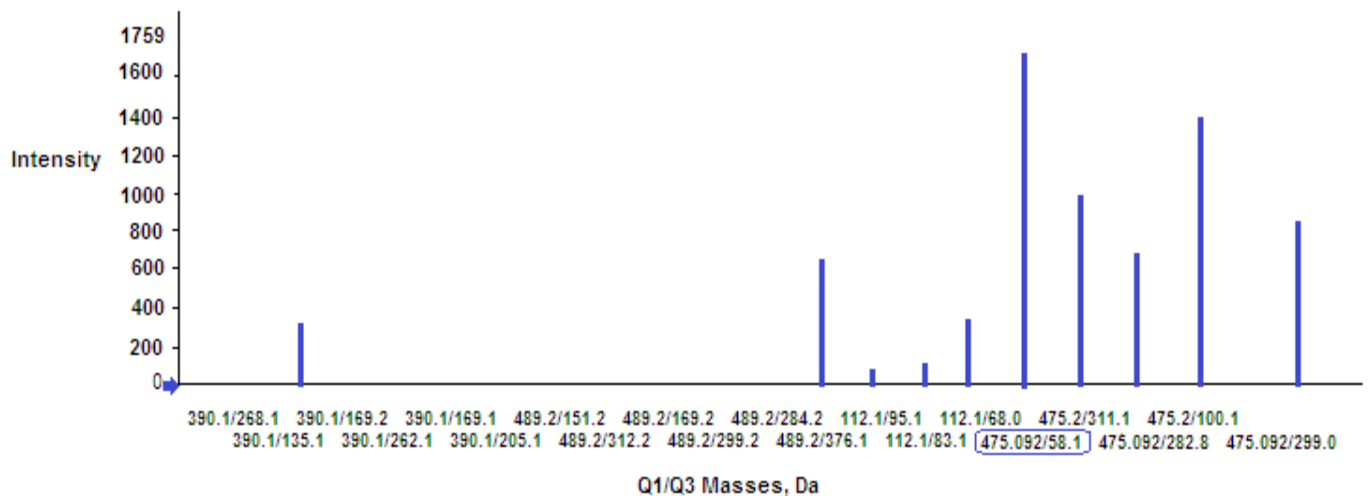

Gambar 2. Spektrum Massa Sildenafil Sitrat

Uji pendahuluan dilakukan dengan tujuan untuk menentukan massa molekul BKO dari sildenafil sitrat, vardenafil, dan tadalafil dan massa pecahannya. Larutan sildenafil sitrat 1 ppm disuntikkan ke dalam spektroskopi massa kemudian ditentukan kondisi optimal. Kondisi optimal untuk sildenafil sitrat yaitu $\mathrm{ES}+$, source temperature $120{ }^{\circ} \mathrm{C}$, desolvation temperature $350{ }^{\circ} \mathrm{C}$, cone 40 volt, Collision 29 volt, dihasilkan spektrum yang menunjukkan massa molekul dan massa pecahan. Massa molekul sildenafil sitrat yang dideteksi oleh spektroskopi massa adalah 475,092 dan massa pecahannya adalah 58.1 dengan polaritas positif (Gambar 10).

Hasil analisis kandungan sildenafil sitrat dalam jamu kuat diperoleh bahwa di kecamatan Bogor Barat sampel yang memiliki waktu retensi sesuai dengan standar sildenafil sitrat yaitu 1.960 menit berjumlah 3 sampel dengan kode A4 pada waktu retensi1.957 menit, A13 pada waktu retensi 1.953 menit dan A 17 pada waktu retensi 1.952 menit. Pada ketiga sampel tersebut memiliki masa/muatan $(\mathrm{m} / \mathrm{z})$ sebesar 475.1/58.1 yang sesuai dengan $\mathrm{m} / \mathrm{z}$ dari standar sildenafil sitrat (Tabel 3). Penelitian pada Kecamatan Tanah Sareal didapatkan hasil 2 sampel dari 14 sampel yang dianalisis memiliki massa/muatan yang sama dengan standar sildenafil sitrat yaitu 475,1/58,1 dan waktu retensi yang ditujukkan mendekati waktu retensi standar dimana sampel dengan kode B4 memiliki waktu retensi 1.953 menit dan sampel B13 pada waktu retensi 1.956 menit. (Tabel 4)

Hasil uji menunjukkan bahwa 5 dari 32 sampel jamu positif mengandung sildenafil sitrat dimana diketahui waktu retensi sampel yang muncul berada di area waktu retensi standar dan massa/muatan $(\mathrm{m} / \mathrm{z})$ dari sampel sesuai dengan massa/muatan $(\mathrm{m} / \mathrm{z})$ dari standar. Hal ini menunjukkan bahwa masih terdapat bahan kimia obat yang tidak diizinkan menurut peraturan Menteri Kesehatan RI No 246 tahun 1990 untuk dijual dan dikonsumsi 
oleh masyarakat dengan adanya jamu kuat yang mengandung bahan kimia oba Tabel3. Hasil Analisis KCMS Sampel Jamu kuat

\begin{tabular}{cccc}
\hline Kode sampel & $\begin{array}{c}\text { Waktu } \\
\text { retensi }\end{array}$ & $\begin{array}{c}\mathbf{m} / \mathbf{z} \\
\text { sildenafil sitrat }\end{array}$ & Sildenafil sitrat \\
\hline Standar & 1,960 & $475.1 / 58.1$ & \\
A1 & - & $201.1 / 91.1$ & Negatif \\
A2 & - & $308.2 / 237.2$ & Negatif \\
A3 & - & $308.2 / 237.2$ & Negatif \\
A4 & 1.957 & $475.1 / 58.1$ & Positif \\
A5 & - & $317.2 / 199.2$ & Negatif \\
A6 & - & $326.2 / 100.1$ & Negatif \\
A7 & - & $146.2 / 128.1$ & Negatif \\
A8 & - & $593.3 / 253.2$ & Negatif \\
A9 & - & $261.2 / 143.2$ & Negatif \\
A10 & - & $243.1 / 86.1$ & Negatif \\
A11 & - & $390.1 / 268.1$ & Negatif \\
A12 & - & $390.1 / 268.1$ & Negatif \\
A13 & 1.953 & $475.1 / 58.1$ & Positif \\
A14 & - & $279.1 / 181.2$ & Negatif \\
A15 & - & $351.2 / 280.2$ & Negatif \\
A16 & - & $325.2 / 307.2$ & Negatif \\
A17 & 1.952 & $475.1 / 58.1$ & Positif \\
A18 & - & $330.2 / 91.1$ & Negatif \\
\hline
\end{tabular}

Tabel4. Hasil Analisi KCMS Sampel Jamu Kuat

\begin{tabular}{cccl}
\hline Kode sampel & $\begin{array}{c}\text { Waktu } \\
\text { retensi }\end{array}$ & $\begin{array}{c}\text { Massa/muatan } \\
\text { sildenafil sitrat }\end{array}$ & Sildenafil sitrat \\
\hline Standar & 1,960 & $475.1 / 58.1$ & \\
B1 & - & $353.2 / 317.2$ & Negatif \\
B2 & - & $300.2 / 282.2$ & Negatif \\
B3 & - & $302.2 / 284.2$ & Negatif \\
B4 & - & $353.0 / 126.9$ & Negatif \\
B5 & - & $605.3 / 195.1$ & Negatif \\
B6 & - & $355.2 / 337.3$ & Negatif \\
B7 & - & $206.1 / 109.0$ & Negatif \\
B8 & - & $505.3 / 429.2$ & Negatif \\
B9 & - & $339.1 / 177.1$ & Negatif \\
B10 & - & $341.1 / 179.1$ & Negatif \\
B11 & 1.957 & $475.1 / 58.1$ & Positif \\
B12 & - & $230.1 / 112.1$ & Negatif \\
B13 & - & $325.2 / 152.1$ & Negatif \\
B14 & 1.953 & $475.1 / 58.1$ & Positif \\
\hline
\end{tabular}


Perhitungan Kadar Sildenafil Sitrat dalam Sampel Jamu Kuat

Perhitungan Kadar Sildenafil sitrat diperoleh dari persamaan regresi linier deret standar Sildenafil sitrat. Deret standar dibuat sebanyak 5 konsentrasi dan diukur luas areanya. Analisi dilakukan menggunakan KCSM. Hasil pengukuran dapat dilihat pada Tabel

Tabel 5. Hasil Konsentrasi dan Luas Area Larutan Standar

\begin{tabular}{cc}
\hline Konsentrasi (ppb) & Luas area \\
\hline 4.562 & 2050 \\
6.589 & 2845 \\
8.917 & 3758 \\
20.253 & 8205 \\
45.559 & 18132 \\
\hline
\end{tabular}

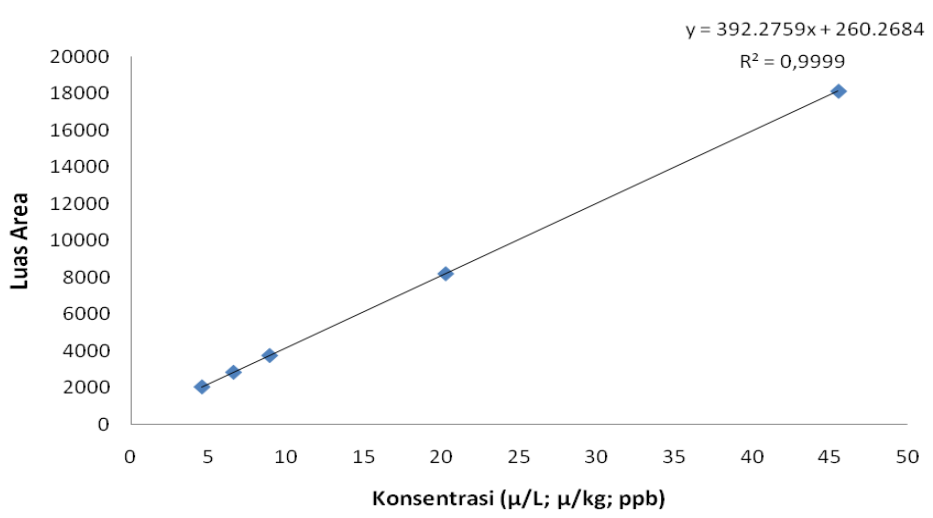

Gambar3. Kurva Regresi Linier Deret standar

Dari hasil Kurva regresi linier diperoleh nilai Slope adalah 392,2759 dan Intercept adalah 260,2684. Nilai $\mathrm{R}^{2}$ adalah 0,9999 yang menunjukkan bahwa kurva ini memberikan hasil yang valid dan dapat digunkan untuk menentukan kadar sildenafil sitrat dalam sampel jamu kuat.

\section{Perhitungan Kadar Sildenafil sitrat}

Perhitungan kadar Sildenafil sitrat dalam jamu kuat diperoleh dengan menggunakan rumus:

(Luas area sampel- intersept) x Volume akhir x fp Slope

\footnotetext{
Kadar zat aktif $(\mu \mathrm{g} / \mathrm{kg})$
}

$$
=
$$$$
\text { Bobot sampel }
$$

Keterangan :

Luas Area Sampel

Fp

Volume akhir $=10 \mathrm{~mL}$

Bobot sampel $=$ bobot dalam satuan gram 
Tabel 6.Perhitungan hasil analisis kuantitatif sampel jamu kuat positif sildenafil sitrat

\begin{tabular}{|c|c|c|c|c|c|c|c|}
\hline $\begin{array}{c}\text { Kode } \\
\text { Sampel }\end{array}$ & $\begin{array}{c}\text { Luas } \\
\operatorname{area}(\mathbf{y})\end{array}$ & $\begin{array}{l}\text { Konsentrasi } \\
\text { Injeksi (x) } \\
\text { (ppb) }\end{array}$ & $\begin{array}{c}\text { Bobot } \\
\text { sampel } \\
\text { (gram) }\end{array}$ & $\mathbf{F p}$ & $\mathbf{V a}$ & $\begin{array}{c}\text { Kadar } \\
(\mathbf{p p b})\end{array}$ & $\begin{array}{c}\text { Rerata kadar } \\
\text { (ppb) }\end{array}$ \\
\hline A4 simplo & 8337 & 20.59 & 1.03120 & \multirow{9}{*}{1} & \multirow{9}{*}{10} & 199.67 & \multirow{2}{*}{198.01} \\
\hline A4 duplo & 8120 & 20.04 & 1.02040 & & & 196.35 & \\
\hline A13 simplo & 47660 & 120.83 & 1.07089 & & & 1128.34 & \multirow{2}{*}{1119.19} \\
\hline A13 dupplo & 43846 & 111.11 & 1.00095 & & & 1110.04 & \\
\hline A17 simplo & 10148 & 25.20 & 1.10996 & & & 227.08 & \multirow{2}{*}{226.00} \\
\hline A17 dupplo & 9971 & 24.75 & 1.10058 & & & 224.92 & \\
\hline B11 simplo & 6522 & 15.96 & 1.00538 & & & 158.76 & \multirow{2}{*}{156.77} \\
\hline B11 duplo & 6357 & 15.54 & 1.00406 & & & 154.78 & \\
\hline B14 simplo & 19764 & 49.72 & 1.11586 & & & 445.58 & 443.87 \\
\hline
\end{tabular}

Dari hasil perhitungan diperoleh hasil kadar sildenafil sitrat dalam sampel jamu kuat sesuai tabel 6, yaitu sampel kode A4, A13, A17, B11, B14 masing-masing dengan kadar 198,01; $1119.19 ; 226,00 ; 156.77 ; 443,87 \mu \mathrm{g} / \mathrm{kg}$. Hasil ini menunjukkan bahwa kelima sampel positif mengandung Bahan Kimia Obat (BKO) sildenafil sitrat.

\section{SIMPULAN}

Berdasarkan hasil penelitian dapat disimpulkan bahwa analisis secara kualitatif menggunakan KLT untuk menguji BKO sildenafil sitrat dan menentukan bobot molekul/ muatan pada KC-SM dapat mengidentifikasi ada atau tidaknya BKO dalam sampel. Analisis kuantitatif dari 32 sampel yang diidentifikasi diduga terdapat 5 sampel yang mengandung sildenafil sitrat yaitu sampel kode A4, A13, A17, B11, B14 masing-masing dengan kadar 198,01; 1119.19; 226,00; 156.77; $443,87 \mu \mathrm{g} / \mathrm{kg}$.

\section{SARAN}

Penelitian lebih lanjut perlu dilakukan proses pengambilan sampel yang lebih merata untuk dapat menggambarkan penggunaan jamu kuat yang mengandung BKO di seluruh Kecamatan Kota Bogor.
[1] [BPOM] Badan Pengawas Obat dan Makanan. 2014. Public Warning No.HM.04.01.1.43.11.14.7054. Jakarta: Badan Pengawas Obat dan Makanan Republik Indonesia.

[2] Mehta, S. 2003. Sildenafil for pulmonary arterial hypertension: Exciting, but protection required. Chest 2003; 123:98992.

[3] Goldstein I, Lue TF, Padma-Nathan H, Rosen RC, Steers WD, Wicker PA. 1998. Oral Sidelnafil on the treatment of erctile dysfunction. Med;338:1397-1404.

[4] Sarigih, T.W, Angga., Anjar M.K., Pri Isnawati U. Analisis Sildenafil Sitrat Pada Jamu Tradisional Kuat Lelaki Merk A dan B dengan metode Kromatografi Cair Kinerja Tinggi [Abstrak]. Didalam: PHARMACY editor. ISSN 1693-3591; Purwokerto, 2 Agustus 2010. Purwokerto: Fakultas Farmasi Universitas Muhammadiyah. Hlm 24.

[5] Suhanda. 2001. Spektroskopi Massa. Bandung : UPI Bandung.

\section{DAFTAR PUSTAKA}


[6] Kartasasmita, R.E., Mulja, Muhammad., Satiadarma, Kosasih., Tjahjono, D.H. 2004. Asas Pengembangan Prosedur Analisis. Cetakan 1. Edisi 1. Surabaya : Airlangga University Press.

[7] Awofisayo, O.A, Awofisayo, O.S, Eyen,N. 2010. Development of basic test for sildenafil citrate and sildenafil citrate tablet. Clinical Medicine and Research 2(11) : 175-179.

[8] Schreiber A., H. El Aribi, T. Sasaki. 2004. " A Novel turn-key LC/MS/MS replacement strategy for traditional LC/UV drug screening" App. NoteCliquid Method ABSCIEX (Experimental Conditions to Analyze Drugs using the MRM Catalogue), Canada, Concord, Ontario.

[9] Galen W, Ewing. 1985. Instrumental of Chemical Analysis Fifthedition. Singapore : McGraw-Hill.

[10] Rohman, A. 2009. Kromatografi untuk Analisa Obat. Yogyakarta : Graha Ilmu 